\title{
Transaksi Ekonomi Klasik Masyarakat Aceh (Analisis Kelayakan Taqnin Hukum Ekonomi Syariah)
}

\author{
Fahriansah \\ Dosen Fakultas Ekonomi Dan Bisnis Islam \\ fahriansah@gmail.com
}

\begin{abstract}
Aceh is one of provinces in Indonesia (NKRI) granted special freedom to regulate households independently (formal juridical) in accordance with Islamic Shari'a. Islamic syariat covers about the economy. Economic activity in Aceh has special characteristics that are not against Islamic law, such as mawah, gala, and peublo aqad. Therefore, formal regulation is required to protect the business people and to safeguard Acehnese culture.
\end{abstract}

Keywords: Aceh culture, legislation feasibility, economic law, sharia.

\begin{abstract}
Abstrak
Aceh adalah salah satu dari tiga puluh empat provinsi di Negara Kesatuan Republik Indonesia (NKRI) yang diberikan kebebasan secara khusus untuk mengatur rumah tangga secara independen (yuridis formal) sesuai dengan syariat Islam. Syariat Islam mencakup tentang ekonomi. Aktifitas ekonomi di Aceh memiliki ciri-ciri khas yang tidak bertentangan dengan syariat Islam seperti mawah, gala, peublo aqad dll. Untuk itu dibutuhkan sebuah langkah pelegeslasian yang bertujuan untuk memberikan payung hukum bagi pelaku serta untuk menjaga kebudayaan Aceh.
\end{abstract}

Kata kunci: budaya Aceh, kelayakan legislasi, hukum ekonomi, syariah.

\section{PENDAHULUAN}

Aceh adalah salah satu dari tiga puluh empat provinsi Negara Kesatuan Repblik Indonesia (NKRI). Pemerintah Indonesia telah memberikan kebebasan kepada Aceh untuk mengatur rumah tangga secara independen/yuridis formal (Muhammad Syahrial, 2012:56), melalui Undang-Undang (UU) Republik Indonesia (RI) tentang Penyelenggaraan Keistimewaan Provinsi Daerah Istimewa Aceh Nomor 44 Tahun 1999 Pasal 3 ayat (2) yang berbunyi: Penyelenggaraan Keistimewaan meliputi: (a) penyelenggaraan kehidupan 
beragama, (b) penyelenggaraan kehidupan adat, (c) penyelenggaraan pendidikan, dan (d) peran ulama dalam menetapkan kebijakan daerah. Penyelenggaraan Keistimewaan Aceh semakin mantap dengan keluarnya UU RI tentang Pemerintahan Aceh Nomor 11 Tahun 2006, yang disebutkan dalam Pasal 272 bahwa dengan berlakunya Undang-undang ini, Undang-undang Nomor 18 Tahun 2001 tentang Otonomi Khusus bagi Daerah Istimewa Aceh sebagai Provinsi Nanggroe Aceh Darussalam dicabut dan dinyatakan tidak berlaku. (Dinas Syari'at Islam Provinsi Nanggroe Aceh Darussalam, 2010:4)

Pemberlakuan poin (a) penyelenggaraan kehidupan beragama, dalam UU RI Nomor 44 Tahun 1999 Pasal 3 ayat (2) yang kaffah, (Kaffah dalam tulisan ini didefinisikan sesuai dengan apa yang dimaksudkan dalam Undang-Undang Nomor: 11 tahun 2006 tentang Pemerintahan Aceh Bab XVII tentang Syari'at Islam dan Pelaksanaannya, Pasal 125 ayat 2 yang menyatakan pelaksanaan syar'at Islam meliputi Ibadah, ahwal syakhshiyyah (hukum keluarga), muamalah (hukum perdata), jinayah (hukum pidana) qadha' (peradilan), tarbiyah (pendidikan, dakwah, syi'ar dan pembelaan Islam), sudah seharusnya diberlakukan hukum ekonomi syariah. Karena hukum ekonomi Islam tidak dapat dipisahkan dari hukum Islam itu sendiri. Artinya, hukum ekonomi Islam adalah satu bagian dari hukum Islam secara keseluruhan. Dengan demikian, maka membincangkan hukum ekonomi Islam menuntut adanya perhatian yang sama terhadap keberadaan hukum Islam itu sendiri (Bambang Iswanto, 2013: 4).

Aceh sejak masa kerajaan Atjeh Darussalam, masyarakatya dikenal telah membudayakan aktifitas ekonomi yang bernilai Islam. Sebagaimana yang disebut dalam buku Adat Aceh bahwa "Pada berdjual beli di Atjeh pernah djuga dahulu diikat perdjandjian, misalnja kalau dalam tempo tiga hari terhitung mulai dari hari berdjual-beli, tidak ada bantahan, maka perdjualan berlaku terus" yang merupakan ketentuan hak khiar jual beli dalam hukum ekonomi Islam. Dan dalam ketentuan peminjaman bahwa "seseorang jang memindjamkan padi atau 
beras, harus dibajar kembali dengan barang itu djuga terketjuali ada diperbuat suatu perdjandjian lain. Dalam hal inipun tidak dibenarkan orang makan riba" (Moehammad Hoesin, 1970:167-168).

Ekonomi (economic) adalah segala aktivitas yang berkaitan dengan produksi dan distribusi di antara orang-orang. Rahardjo melengkapi definisi tersebut dengan menginformasikan pengertian ekonomi yang lebih lengkap yang dikutif dari buku The Pinguin Dictionary of Economics yang menjelaskan bahwa ekonomi adalah kajian tentang produksi, distribusi, dan konsumsi kekayaan dalam masyarakat manusia. Rahardjo menjelaskan bahwa definisi yang terdapat dalam buku tersebut lebih lengkap karena menjelaskan obyek ekonomi (yaitu kekayaan) dan aspek konsumsi (sebagai kegiatan ekonomi), (M. Dawam Rahardjo, 1999:5-6). Sementara Boediono menjelaskan bahwa manusia dari segi ekonomi melakukan tiga kegiatan pokok: produksi, konsumsi, dan pertukaran, (Boediono, 1982:1). Rahardjo dalam kaitannya dengan arti ekonomi, menawarkan tiga kemungkinan makna ekonomi Islam: 1) ekonomi Islam yang dimaksud adalah "ilmu ekonomi” yang berdasarkan nilai-nilai atau ajaran Islam; 2) ekonomi Islam yang dimaksud adalah "sistem ekonomi;" dan 3), ekonomi Islam yang dimaksud adalah “perkenonomian dunia/negara- negara Islam"(M. Dawam Rahardjo, 1999:3-4).

Menurut Hasanuzzaman, ekonomi Islam adalah pengetahuan dan penerapan hukum syariah untuk mencegah terjadinya ketidakadilan atas pemanfaatan sumber-sumber material guna memberikan kepuasan (pada manusia) dan dilakukan dalam rangka menjalankan kewajiban kepada Allah dan masyarakat; dan M. Akram Khan menjelaskan bahwa ekonomi Islam bertujuan untuk mempelajari keunggulan manusia yang dicapai melalui pengorganisasian sumber daya alam yang didasarkan pada kerjasama dan partisipasi (Muhammad, 2004:6-7).

Selain arti ekonomi, dalam ilmu hukum dikenal juga terminologi lain yang sekarang sangat terkenal di Indonesia, yaitu bisnis. Arti bisnis adalah "the 
buying and selling of goods and services". Skinner menjelaskan bahwa bisnis adalah pertukaran barang, jasa, atau uang yang saling menguntungkan atau memberikan manfaat. Perbedaan antara kegiatan bisnis dan kegiatan ekonomi antara lain terletak pada tujuan. Tujuan ekonomi adalah untuk mencapai kondisi kesejahteraan fisik; sedangkan tujuan bisnis adalah untuk: 1) mendapatkan keuntungan, 2) mempertahankan kelangsungan hidup perusahaan, 3) pertumbuhan perusahaan, dan 4) tanggung jawab sosial (Pandji Anoraga, 2004:3-14). Husen Umar menegaskan bahwa tujuan utama bisnis adalah laba atau keuntungan (Husein Umar, 2003:4).

Kehadiran ekonomi Islam oleh banyak kalangan dinilai sebagai salah satu upaya untuk keluar dari jeratan dua kekuatan utama ekonomi dunia, kapitalisme dan sosialisme. la hadir dengan menawarkan konsep ekonomi religius yang diyakini merujuk langsung dari dua sumber hukum Islam, alQur'an dan as-Sunnah. Itulah sebabnya ekonomi Islam disebut juga dengan ekonomi syariah atau ekonomi al-Qur'an. Nama yang pertama menjadi justifikasi bahwa ekonomi Islam adalah bagian mata rantai dari syariah, sistem norma kongkret dalam Islam. Sedangkan yang kedua menegaskan sumber utama dari ekonomi Islam adalah al-Qur'an, wahyu Allah.

Seiring perkembangan bisnis Ummat Islam berdasar syariah semakin menunjukkan kemajuan, maka kebutuhan akan lembaga yang dapat menyelesaikan persengketaan yang terjadi atau mungkin terjadi dengan perdamaian dan prosesnya secara cepat merupakan suatu kebutuhan yang sangat mendesak. Majelis Ulama Indonesia (MUI) memprakarsai berdirinya BAMUI dan mulai dioperasionalkan pada tanggal 1 Oktober 1993. Adapun tujuan dibentuk BAMUI adalah : Pertama, memberikan penyelasaian yang adil dan cepat dalam sengketa-sengketa muamalah perdata yang timbul dalam bidang perdagangan, industry, keuangan, jasa, dan lain-lain. Kedua, menerima permintaan yang diajukan oleh para pihak dalam suatu perjanjian 
tanpa adanya suatu sengketa untuk memberikan suatu pendapat yang mengikat mengenai suatu persoalan berkenaan dengan perjanjian tersebut.

Syarat utama untuk menjadi arbiter tunggal atau arbiter majelis diantaranya adalah beragama Islam yang taat menjalankan agamanya dan tidak terkena larangan berdasarkan peraturan perundang-undangan yang berlaku. Oleh karena itu dalam penyelesaian sengketa ekonomi syariah dibutuhkan sebuah aturan formal sebagai rujukan hakim. Pembuatan hukum formal khusus ekonomi syariah di Aceh dapat dilakukan melalui proses taqnin hukum ekonomi syariah. Dengan pertumbuhan dan perkembangan kegiatan ekonomi syariah, maka peluang terjadinya sengketa, konflik (dispute) antara para pelaku ekonomi syariah juga semakin besar. Suatu sengketa bermula dari perselisihan paham yang kemudian berlarut-larut tidak terselesaikan antara para subjek hukum yang sebelumnya telah mengadakan hubungan hukum perjanjian, sehingga pelaksanaan hak dan kewajiban yang ditimbulkannya berjalan tidak harmonis (Suyud Margono, 2000:12).

Berdasarkan uraian problematis di atas, maka permasalahan kelayakan legislasi hukum perdata (ekonomi) syariah di Aceh merupakan proyek besar yang harus dikaji secara proporsional sehingga dapat meminimalisir masalah utama legislasi Qanun dalam rangka penerapan syari'at Islam di Aceh yang berhubungan dengan instrumen hukum, kelembagaan hukum dan budaya hukum ('Asham Muhammad Syabaru, 1408 H :25-26). Permasalahan kelayakan taqnin hukum ekonomi syariah ini menjadi kajian utama, sebagai konsekwensi dan tanggung jawab akademik dalam menyikapi penerapan syariat Islam di Aceh dalam bingkai hukum nasional (Muhammad Faruq, al-Nabhan, 1981:351). Dengan demikian dapat mengidentifikasi keinginan lahirnya qanun ekonomi syariah, karena tidak adanya landasan dan asas-asas hukum yang menjadi pedoman proses legislasi hukum di Aceh. 


\section{Perbandingan Sistem Ekonomi Kapitalis, Sosialis dan Islam (Syariah)}

\section{Sistem Ekonomi Kapitalis}

Sistem ekonomi kapitalis dan sosialis merupakan perwakilan dari sistem ekonomi blok Barat dan Timur. Kedua sistem tersebut, dalam perjalannya, terbagi lagi ke dalam berbagai bentuk. Dalam konteks ekonomi, kedua sistem ini telah mampu membawa kemakmuran pada negara penganutnya, seperti Amerika dan Uni Soviet.

Abad ke-18 merupakan awal dimulainya paham kapitalisme, yang berasal dari Inggris dan selanjutnya menyebar ke wilayah Eropa Barat dan Amerika Utara. Dasar filosofis yang digunakan dalam sistem ekonomi kapitalis bersumber dari tulisan Adam Smith pada tahun 1776 di dalam bukunya yang berjudul An Inquiry in to The Nature and Causes of The Wealth of Nations. Buku tersebut berisi tentang pemikiran-pemikiran tingkah laku hukum ekonomi masyarakat (Robert L. Heilbroner, 1986:85).

Ekonomi konvensional, lahir dari paradigma enlightenment yang ditandai dengan pendekatan utama untuk mewujudkan kesejahteraan manusia analisisnya tentang problem-problem manusia yang bersifat sekuler. Sekuler di sini dimaksudkan sebagai lebih mementingkan konsumsi dan pemilikan materi sebagai sumber kebahagiaan manusia, tanpa mengindahkan peranan nilai moral dalam reformasi individu dan sosial, terlalu berlebihan menekankan peranan pasar atau negara. la tidak memiliki komitmen kuat kepada persaudaraan (brotherhood) dan keadilan sosio-ekonomi dan tidak pula memiliki mekanisme filter nilai-nilai moral (Agustianto, 9 Desember 2007).

Sistem ekonomi kapitalis yang murni merupakan buah pemikiran Adam Smith dipengaruhi oleh semangat mendapatkan keuntungan semaksimal mungkin dengan sumber daya yang terbatas. Kapitalis mengakui kebebasan manusia tidak bisa bebas lepas tetapi kebebasan manusia dibatasi oleh 
kebebasan orang lain. Akibatnya, masing-masing pihak meningkatkan persaingan agar tidak tersingkir dari pasar. Namun demikian, kondisi ini menyebabkan pula orang bertindak tidak benar atau tak bermoral dalam memperoleh keuntungan yang maksimal sehingga manusia cenderung bersifat opportunis dalam memenuhi kebutuhan ekonominya. Dampak lain dari kebebasan dalam kapitalisme adalah menyebabkan sumber produksi dikuasai oleh pengusaha yang memiliki modal besar. Setiap keuntungan mereka digunakan untuk peningkatan produksi. Sementara itu pihak pekerja atau buruh kurang mendapat perhatian. Siklus ini mengakibatkan seorang pengusaha penghasilannya semakin meningkat sedangkan pekerja dari waktu ke waktu tidak mengalami peningkatan.

Secara mendasar, kapitalisme merupakan serangkaian prinsip-prinsip ekonomi yang bersumber dari konsep pribadi dan kewirausahaan. Dalam kehidupan masyarakat kapitalis, sebagian besar perusahaan yang ada pada waktu itu adalah perusahaan profit yang mencari keuntungan sebesarbesarnya. Selain itu, perlengkapan produksi seperti lahan, bangunan dan mesin dimiliki secara pribadi. Para pelaku ekonomi kapitalis, baik produsen maupun konsumen sama- sama ingin memenuhi hasrat mereka untuk menciptakan dan mengkonsumsi barang ataupun jasa sebagai alat pemuas kebutuhan. Hal itu semakin terlihat ketika negara di benua eropa khusunya Inggris dan juga Amerika mengizinkan perusahaan-perusahaan untuk membangun pabrik tekstil yang besar, rel kereta api yang mahal, ladang minyak raksasa, operasi pertambangan, serta tangki perapian baja tanpa adanya pemungutan dana retribusi dari pihak pemerintah. Sayangnya, hal tersebut justru dianggap sebagai simbol kesuksesan, bukan merupakan simbol kerakusan (Jeffry Admund Curry, 2000:21).

Meskipun demikian, ekonomi kapitalis yang erat akan budaya konvensional telah menuai banyak kritikan dari berbagai kalangan. Mulai dari Karl Max, Joseph Schumpeter, hingga Joseph Stigliz. Saat ini, di awal abad 
21, kritikan tersebut semakin tajam karena banyak indikasi yang menunujukan kegagalan sistem ekonomi kapitalisme. Pertama, penggunaan sistem ribawi pada sistem perekonomian ini telah menimbulkan ketimpangan dan ketidakadilan ekonomi. Dimana orang yang memiliki banyak harta semakin memperkaya dirinya tanpa memperhatikan orang-orang di sekitarnya, dan orang yang miskin semakin miskin. Kedua, ekonomi kapitalisme juga sudah menciptakan krisis moneter. Ketiga, ekonomi kapital telah melakukan banyak kesalahan dalam sejumlah premisnya, terutama rasionalitas ekonomi yang telah mengabaikan dimensi moral (Siti Nurhayati, 2009:20).

Sekularisme menafikan peran agama dalam ekonomi, maka dalam masalah kepemilikan, kapitalisme memandang bahwa asal usul adanya kepemilikan suatu barang adalah terletak pada nilai manfaat (utility) yang melekat pada barang itu, yaitu sejauh mana ia dapat memuaskan kebutuhan manusia. Jika suatu barang mempunyai potensi dapat memuaskan kebutuhan manusia, maka barang itu sah untuk dimiliki, walaupun haram menurut agama, misalnya babi, minuman keras, dan narkoba. Ini berbeda dengan ekonomi Islam, yang memandang bahwa asal usul kepemilikan adalah adanya izin dari Allah SWT (idzn Asy-Syâri') kepada manusia untuk memanfaatkan suatu benda. Jika Allah mengizinkan, berarti boleh dimiliki. Tapi jika Allah tidak mengizinkan (yaitu mengharamkan sesuatu) berarti barang itu tidak boleh dimiliki. Maka babi dan minuman keras tidak boleh diperdagangkan karena keduanya telah diharamkan Allah, yaitu telah dilarang kepemilikannya bagi manusia muslim (Taqiy Al-Din An-Nabhani, 1990). Dalam masalah pemanfaatan kepemilikan, kapitalisme tidak membuat batasan tatacaranya (kaifiyah-nya) dan tidak ada pula batasan jumlahnya (kamiyahnya). Sebab pada dasarnya sistem ekonomi kapitalisme adalah cermin dari paham kekebasan (freedom/liberalism) di bidang pemanfaatan hak milik. Maka seseorang boleh memiliki harta dalam jumlah berapa saja dan diperoleh 
dengan cara apa saja. Walhasil tak heran di Barat dibolehkan seorang bekerja dalam usaha perjudian dan pelacuran.

Dalam masalah distribusi kekayaan, kapitalisme menyerahkannya kepada mekanisme pasar, yaitu melalui mekanisme harga keseimbangan yang terbentuk akibat interaksi penawaran (supply) dan permintaan (demand). Harga berfungsi secara informasional, yaitu memberi informasi kepada konsumen mengenai siapa yang mampu memperoleh atau tidak memperoleh suatu barang atau jasa. Karena itulah peran negara dalam distribusi kekayaan sangat terbatas. Negara tidak banyak campur tangan dalam urusan ekonomi, misalnya dalam penentuan harga, upah, dan sebagainya. Metode distribusi ini terbukti gagal, baik dalam skala nasional maupun internasional yang mengakibatkan kesenjangan antara si kaya dengan si miskin sedemikian lebar.

Meminjam istilah Chapra bahwa ekonomi konvensional telah mencapai taraf sofistifikasi intelektual secara sempurna. Akan tetapi bersamaan dengan itu ia mengalami kegagalan besar dalam membantu manusia dalam merealisasikan sasaran humanitariannya seperti keadilan dan kesejahteraan umum. Kegagalan ini, menurut Chapra disebabkan oleh anatema ilmu ekonomi terhadap penilaian (value judgement) dan penekanan yang berlebihan pada maksimalisasi kekayaan dan pemuasan keinginan individual (self interest) (M. Umer Chapra, 2000:Ix). Hal ini tentu berlawanan dengan dasar filosofi mayoritas agama.

Agama-agama pada umumnya sekalipun memandang penting pemenuhan kebutuhan materiil, akan tetapi bukan sebagai tujuan utamanya. Pada intinya, Chapra hendak menyatakan bahwa kegagalan ekonomi konvensional lebih disebabkan oleh pengabaiannya terhadap nilai-nilai, norma, agama dan etika.

\section{Sistem Ekonomi Sosialisme}


Kata sosial, dalam kehidupan masyarakat memiliki banyak arti yang berbeda. Istilah sosialis bisa berarti positif dan bisa juga berarti negatif. Dalam hal ini, sosialis yang dimaksud adalah sistem ekonomi sosialis yang sering kali disebut sosialisme. Sistem ekonomi kapitalis tentu sangat erat kaitannya dengan komunisme yang menjunjung tinggi nilai-nilai kebersamaan tanpa memperhatikan hak individu.

Sosialisme muncul di akhir abad ke-18 dan awal abad ke-19 sebagai reaksi dari perubahan ekonomi dan sosial yang diakibatkan oleh revolusi industri. Revolusi industri ini memang memberikan keberkahan buat para pemilik pabrik pada saat itu, tetapi di lain pihak para pekerja justru malah semakin miskin. Semakin menyebar ide sistem industri kapitalis ini, maka reaksi dalam bentuk pemikiran-pemikiran sosialis pun semakin meningkat. Pada tahun 1840-an, istilah komunisme mulai muncul untuk menyebut sayap kiri yang militan dari Paham sosialisme. Istilah ini biasanya dirujukkan kepada tulisan Etiene Cabet dengan teori-teorinya tentang kepemilikan umum. Istilah ini kemudian digunakan oleh Karl Marx dan Friedrich Engels untuk menggambarkan pergerakan yang membela perjuangan kelas dan mengaruskan revolusi untuk menciptakan sebuah masyarakat kerjasama (society of cooperation).

John Stuart Mill (1806-1873) mengatakan bahwa sosialisme dapat diartikan sebagai bentuk perekoomian, dimana pemerintah bertindak sebagai pihak yang dapat dipercaya oleh masyarakat, dan menasionalisasikan industri besar dan strategis seperti pertambangan, jalan, dan jembatan, kereta api, serta perusahaan lain yang menyangkut hajat hidup orang banyak. Sosialisme dalam arti yang sesungguhnya, menghapuskan adanya kepemilikan swasta dan menjadikan alat-alat produksi maupun tanah pertanian sebagai milik negara.

Pemikiran Sosialisme diadopsi dari pemikiran Karl Marx (1818-1883) yang dilembagakan oleh Lenin dalam sebuah negara yang bernama Uni 
Soviet. Setelah runtuhnya Uni Soviet pada tahun 1991, pengaruh sistem sosialis berkurang. Akan tetapi beberapa negara yang masih menggunakan sistem sosialis, berusaha menerima mainstream sistem yang berlaku di sekitarnya sehingga muncullah sistem sosialis pasar, sistem yang mengakui keberadaan pasar dalam mengatur mekanisme perekonomian dalam negerinya (Heru Sudarsono, 2002:85).

Sistem ekonomi sosialis mempunyai tujuan kamakmuran bersama, filosofi ekonomi sosialis adalah bagaimana mendapatkan kesejahteraan, perkembangan sosialiis dimulai dari kritik terhadap kapitalisme yang ada waktu itu kaum kapitalis dan kaum borjuis mendapat legitimasi gereja untuk mengeksploitasi buruh. Inilah yang menjadikan Karl Marx mengkritik sistem kapitalis sebagai ekonomi yang tidak sesuai dengan aspek kemasyarakatan. Menurut Marx, tidak ada tempat bagi kapitalisme dialam kehidupan, maka upaya revolusioner harus di lakukan untuk menghancurkan kapitalisme, alatalat produksi harus dikuasai oleh negara guna melindungi rakyat. Kritik Marx atau kapitalisme ini diimplementasikan oleh Lenin dalam bentuk institusi negara.

Sistem sosialis adalah hasil dari kritik terhadap sistem kapitalis, dimana kapitalis dianggap sebagai kaum borjuis mendapat legitimasi untuk mengeksploitasi buruh. Maka lahirlah sebuah sistem yang mengatasnamakan kesejahteraan rakyat dan kemakmuran bersama. Semuanya dapat dicapai jika alat-alat produksi dikuasai oleh negara. Untuk itulah, maka Lenin mengupayakan revolusi terhadap sistem ekonomi di Rusia. Sistem ekonomi sosialis menyediakan kebutuhan pokok bagi rakyatnya dan berdasarkan perencanaan negara. Keadaan ini menyebabkan negara memiliki rakyat sepenuhnya sebagai kompensasi dari pemenuhan kebutuhan oleh negara dan rakyat tidak dapat mengapresiasikan skillnya karena terbelenggu oleh kebijakan Negara. 
Dari sudut pandang ekonomi, sosialisme adalah sebuah sistem ekonomi yang dilandaskan pada prisip kebersamaan, di mana kepemilikan alatalat produksi (means of production) dan distribusi bersifat kolektif (Deliarnov, 2006:39). Salah satu bentuknya yang paling ekstrim adalah komunisme, dimana keputusan-keputusan ekonomi disusun, direncanakan dan sekaligus dikontrol oleh negara. Sebagai respon terhadap era industrialisasi, sistem ekonomi sosialis dimana Karl Marx sebagai rujukan utamanya, gencar mengkritik ekonomi pasar yang dikembangkan oleh Adam Smith. Dalam kaca mata sosialis, kapitalisme adalah sistem yang tidak adil dan "busuk dari dalam". Dari sudut moral, kapitalisme mewarisi ketidak adilan sebab ketidak pedulian pada ketimpangan dan kesenjangan social dalam masyarakat. Dari sudut social, sosialis memandang kapitalisme sebagai sumber konflik antar kelas, baik yang borjuis dan proletar, antara tuan tanah dan buruh, dimana yang satu berperan sebagai penindas (oppressor) sedang yang lainnya sebagai yang tertindas (oppressed). Dari sudut ekonomi, sosialis memandang kapitalisme tidak lain hanyalah alat bagi kapitalis untuk mengejar laba. Sedangkan ekonomi pasar yang diciptakan kapitalisme bukanlah sebuah mekanisme untuk memaksimumkan kesejahteraan privat individu-individu, melainkan sebagai untuk memfasilitasi ketamakan para kapitalis mengangkangi nilai surplus (surplus value) dan mengakumulasikan kekayaan (Deliarnov, 2006:41-43).

Ada sebuah ungkapaan yang tepat untuk menggambarkan keadaan ekonomi sosialis yang syarat dengan prinsip kebersamaan dalam mengutamakan rakyatnya, namun seringkali mengabaikan hak-hak ekonomi secara individu. Seperti di Rusia, bahan makanan yang dibeli oleh masyarakat mungkin saja ditanam di lahan pertanian milik negara dan dijual disebuah toko milik negara. Petani sebagai seorang buruh pekerja perorangan menerima gaji untuk pekerjaan mereka. Namun, sejatinya mereka melakukan hal tersebut karena diarahkan oleh pemerintah secara terperinci (Gregory Grossman, 
1995:45). Dari kisah tersebut dapat digambarkan bahwa, sang petani tidak menikmati hasil panen secara utuh, karena sang petani tidak akan mendapatkan uang lebih selain dari gaji pemerintah meskipun hasil panen yang dihasilkan lebih banyak daripada biasanya. Kisah ini merupakan sebuah penggalan dari sistem ekonomi sosialis yang dianut oleh negara-negara komunis di dunia.

Konsep komunis hanya mengakui kepemilikan bersama, sedangkan konsep kapitalis hanya menonjolkan peruntukan pribadi saja. Sistem ekonomi islam melihat akan pentingnya kepemilikan yang berintegrasi pada waktu yang sama, yang disebut dengan kepemilikan muzdawijah, yaitu mengakui adanya kepemilikan pribadi serta kepemilikan bersama dan bernegara (Jafril Khalil, 2010:115).

\section{Sistem Ekonomi Islam}

Kemunculan sistem ekonomi Islam, baik di tingkat dunia maupun Indonesia seperti yang kita saksikan sejak sekitar tiga atau empat dekade belakangan ini menimbulkan berbagai pandangan dan sikap. Ada yang menentangnya, ada yang skeptis, ada pula yang akomodatif, namun ada pula yang malah menerima dengan tangan terbuka. Ekonomi Islam dapat didefinisikan sebagai sebuah studi tentang pengelolaan harta benda menurut perpektif Islam (tadbîr syu"un al-mâl min wijhah nazhar al-islam) (An-Nabhani, 1990).

Secara epistemologis, ekonomi Islam dibagi menjadi dua disiplin ilmu; Pertama, ekonomi Islam normatif, yaitu studi tentang hukum-hukum syariah Islam yang berkaitan dengan urusan harta benda (al-mâl). Cakupannya adalah: (1) kepemilikan (al-milkiyah), (2) pemanfaatan kepemilikan (tasharruf fi almilkiyah), dan (3) distribusi kekayaan kepada masyarakat (tauzi' al-tsarwah baina al-nas). Bagian ini merupakan pemikiran yang terikat nilai (value-bond) atau valuational, karena diperoleh dari sumber nilai Islam yaitu Al-Qur’an dan 
As-Sunnah, melalui metode deduksi (istinbath) hukum syariah dari sumber hukum Islam yaitu al-Qurean dan as-Sunnah. Ekonomi Islam normatif ini oleh Syaikh Taqiyuddin an-Nabhani disebut sistem ekonomi Islam (an-nizham al-iqtishadi fi al-Islâm). Kedua, ekonomi Islam positif, yaitu studi tentang konsep-konsep Islam yang berkaitan dengan urusan harta benda, khususnya yang berkaitan dengan produksi barang dan jasa. Cakupannya adalah segala macam cara (uslub) dan sarana (wasilah) yang digunakan dalam proses produksi barang dan jasa. Bagian ini merupakan pemikiran universal, karena diperoleh dari pengalaman dan fakta empiris, melalui metode induksi (istiqra') terhadap fakta-fakta empiris parsial dan generalisasinya menjadi suatu kaidah atau konsep umum (S. Waqar Ahmed Husaini, 2002).

Sistem ekonomi Islam merupakan sistem yang berbeda dengan kapitalisme dan sosialisme. Namun merupakan Ummatan Washatan, yaitu umat yang menganut sistem yang tidak ekstrim melainkan berada di tengahtengah dan mengambil keuntungan atau manfaat serta melepas sifat buruk dari kedua sistem tersebut. Islam memandang persoalan ekonomi tidak dari perspektif kapitalis, yang memberikan kebebasan dan hak pemilikan tak terbatas pada setiap individu serta mendukung eksploitasi seseorang. Juga tidak memandang dari perspektif komunis yang ingin merampas semua hak individu dan menjadikan individu semata-mata sebagai budak ekonomi yang dikendalikan Negara. Tetapi memberi perhatian pada naluri keegoisan manusia tanpa membiarkannya menjadi berbahaya bagi masyarakat (Fazalur Rahman, 1982:49). Konsep ekonomi Islam merupakan modifikasi antara pendidikan dan moral. Langkah tersebut diambil untuk menghindar manusia dari ketamakan dan intoleransi seperti dalam kapitalis dan melindungi hak-hak rakyat dari kediktatoran sosialisme.

Umar Chapra menyebut ekonomi Islam dengan Ekonomi Tauhid. Tapi secara umum dapat dikatakan sebagai divine economics. Cerminan watak 
“Ketuhanan" ekonomi Islam bukan pada aspek pelaku ekonominya — sebab pelakunya pasti manusia - tetapi pada aspek aturan atau sistem yang harus dipedomani oleh para pelaku ekonomi. Ini didasarkan pada keyakinan bahwa semua faktor ekonomi termasuk diri manusia pada dasarnya adalah kepunyaan Allah, dan kepadaNya (kepada aturanNya) dikembalikan segala urusan.

Hubungan ekonomi Islam dengan akidah Islam tampak jelas dalam banyak hal, seperti pandangan Islam terhadap alam semesta yang “ditundukkan" (disediakan) untuk melayani kepentingan manusia. Hubungan ekonomi Islam dengan akidah dan syariah (hukum) tersebut memungkinkan aktivitas ekonomi dalam Islam menjadi ibadah (perbuatan taat kepada Allah), bertujuan luhur dan mengandung pengawasan ketat (Ali Yafie. dkk, 2003:38). Dalam hidup manusia, segala perbuatan manusia di bumi ini untuk mendapat kebaikan di dunia dan akhirat termasuk persoalan ekonomi karena ekonomi menyangkut hajat hidup manusia maka sepak terjangnya telah diatur dalam Alquran: al-Jumu'ah (62) : 10, "Apabila telah ditunaikan sembahyang, maka bertebaranlah kamu di muka bumi dan carilah karunia Allah dan ingatlah Allah sebanyak-banyaknya supaya kamu beruntung. Berdasarkan ayat di atas, maka manusia selain dituntut untuk meningkatkan kesejahteraan juga tidak melupakan proses peningkatan tersebut dengan jalan yang baik dan benar yaitu jalan yang diridai Allah swt. Dengan demikian, bahwa kebaikan di dunia dijadikan golden bridge (jembatan emas) untuk mencapai kehidupan yang baik di akhirat kelak. Jika demikian, maka tidak ada nilai report merah dalam semua bentuk kehidupan.

Islam menawarkan sistem yang sangat moderat untuk perbaikan ekonomi masyarakat. Sistem menjadi bekal untuk menciptakan stabilitas ekonomi dan keseimbangan dan memberi peluang yang seimbang antara hakhak alami pada setiap oran yakni kebebasan berusaha dan pada saat yang sama menjaga keseimbangan pemerataan kekayaan. Dalam sistem Ekonomi 
Islam terdapat larangan mengumpulkan kekayaan secara berlebihan, seorang muslim berkewajiban menjaga dirinya agar terhindar dari sifat yang berlebihlebihan dalam harta, sebagaimana dalam QS. Al-Maidah (5) : 87, “...Dan janganlah melampaui batas. Sesungguhnya Allah tidak menyukai orang-orang yang melampaui batas". Islam merumuskan suatu sistem yang konplit, yaitu sebuah sistem ekonomi yang memiliki akar syariah yang kuat. Hal ini berbekal pada keyakinan bahwa sebagai khalifah di bumi, seharusnya memanfaatkan kekhalifahannya untuk kesejahteraan dunia dan akhirat dan pemenuhan kebutuhan ruhani dan materi secara seimbang.

Berbeda dari sistem sekuler yang menguasai dunia dewasa ini, tujuantujuan Islam (maqashid asy-syariah) bukanlah semata-mata bersifat materi. Justru tujuan-tujuan itu diadasarkan pada konsep-konsepnya sendiri mengenai kesejahteraan manusia (falah) dan kehidupan yang baik (hayat thayyibah), yang memberikan nilai yang sangat penting bagi persaudaraan dan keadilan sosio-ekonomi dan menuntut suatu kepuasan yang seimbang, baik dalam kebutuhan-kebutuhan materi maupun ruhani dari seluruh umat manusia (M.Umer Chapra, 1999:8). Dalam pandangan Naqvi, ekonomi Islam terangkum pada empat aksioma, yaitu kesatuan (unity), keseimbangan (equilibrium), kehendak bebas (free will) dan tanggung jawab (responsibility) (Syed Nawab Haider Naqvi, 1994). Keempat aksioma tersebut ditransfer ke dalam etika ekonomi masyarakat dan dijadikan acuan dalam perilaku ekonomi yang konsisten. Bentuk kesatuan merupakan dimensi vertikal manusia terhadap kekuasaan Allah swt. Manusia diberi kebebasan memperoleh dan mempergunakan harta dengan tetap mepertanggung jawabkan kebebasannya agar tetap dalam keridaan Allah sehingga berwujud keseimbangan hidup dunia dan ukhrawi.

Maka paradigma sistem ekonomi Islam ada 2 (dua), yaitu: Pertama, paradigma umum, yaitu Aqidah Islamiyah yang menjadi landasan pemikiran (al-qaidah fikriyah) bagi segala pemikiran Islam, seperti sistem ekonomi 
Islam, sistem politik Islam, sistem pendidikan Islam, dan sebagainya. Aqidah Islamiyah di sini dipahami bukan sekedar sebagai Aqidah Ruhiyah (aqidah spiritual), yakni aqidah yang menjadi landasan aktivitas-aktivitas spiritual murni seperti ibadah, namun juga sebagai Aqidah Siyasiyah (aqidah politis), yakni aqidah yang menjadi landasan untuk mengelola segala aspek kehidupan manusia tanpa kecuali termasuk ekonomi. Kedua, paradigma khusus (cabang), yaitu sejumlah kaidah umum dan mendasar dalam Syariah Islam yang lahir dari Aqidah Islam, yang secara khusus menjadi landasan bangunan sistem ekonomi Islam. Paradigma khusus ini terdiri dari tiga asas (pilar), yaitu: (1) kepemilikan (al-milkiyah) sesuai syariah, (2) pemanfaatan kepemilikan (tasharruf fi al-milkiyah) sesuai syariah, dan (3) distribusi kekayaan kepada masyarakat (tauzi' al-tsarwah baina al-nas), melalui mekanisme syariah. Dalam sistem ekonomi Islam, tiga asas tersebut tidak boleh tidak harus terikat dengan syariah Islam, sebab segala aktivitas manusia (termasuk juga kegiatan ekonomi) wajib terikat atau tunduk kepada syariah Islam. Sesuai kaidah syariah, Al-Ashlu fi al-af'al al-taqayyudu bi al-hukm alsyar'i (Prinsip dasar mengenai perbuatan manusia, adalah wajib terikat dengan syariah Islam) (Atha`Ibnu Khalil, 2000).

Adiwarman Karim dalam bukunya yang berjudul Bank Islam, Analisis Fiqh dan Keuangan, menjelaskan bahwa bangunan ekonomi Islam didasarkan atas lima nilai universal, yaitu:

1. Tauhid (Keimanan). Tauhid merupakan fondasi ajaran Islam. Dengan tauhid, manusia secara menyeluruh akan menyerahkan segala aktifitasnya kepada Allah. Oleh karena itu, segala aktifitas akan selalu dibingkai dalam kerangka hubungan kepada Allah.

2. 'Adl (Keadilan). Dalam Islam, adil didefinisikan sebagai tindakan tidak menzhalimi dan dizhalimi. Implikasi ekonomi dari nilai ini adalah bahwa pelaku ekonomi tidak dibolehkan untuk mengejarkan keuntungan pribadi, namun merugikan orang lain atau merusak alam. 
3. Nubuwwah (Kenabian). Salah satu fungsi dari Rasul adalah untuk menjadi model terbaik bagi manusia yang harus diteladani untuk mendapatkan keselamatan dunia dan akhirat. Nabi Muhammad adalah model terbaik yang utus Allah untuk dijadikan tauladan oleh seluruh manusia. Keteladanan Nabi Muhammad mencakup seluruh aspek kehidupan, termasuk teladan dalam bertransaksi ekonomi dan bisnis. Empat sifat utama Nabi yang dapat dijadikan teladan adalah siddiq, amanah, fathanah, dan tabligh.

4. Khalifah (Pemerintahan). Dalam Al Quran, Allah menyebutkan bahwa manusia diciptakan adalah untuk menjadi khalifah dibumi. Peran khalifah adalah untuk menjadi pemimpin dan pemakmur bumi.

5. Ma'ad (Hasil) Implikasi nilai ini adalah dalam perekonomian dan bisnis bahwa motivasi para pelaku bisnis adalh untuk mendapatkan hasil di dunia (laba/profit) dan hasil di akhirat (pahala), (Adiwarman Karim, 2004).

Kelima nilai dasar ini menjadi dasar inspirasi untuk untuk menyusun proposisi- proposisi dan teori-teori ekonomi Islam. Dari kelima nilai-nilai universal tersebut, dibangunlah tiga prinsip derivatif yang menjadi ciri-ciri dan cikal bakal sistem ekonomi Islam. Ketiga prinsip derivatif itu adalah:

1. Multitype ownership (Kepemilikan Multijenis). Nilai tauhid dan keadilan melahirkan konsep Multitype ownership atau kepemilikan multijenis. Dalam sistem ekonomi kapitalis, prinsip umum kepemilikan yang berlaku adalah kepemilikan swasta atau pemodal, sedang dalam sistem ekonomi sosialis yang berlaku adalah kepemilikan negara. Dalam sistem ekonomi Islam, mengakui bermacam bentuk kepemilikan, baik oleh swasta, negara, atau campuran.

2. Freedom to act (Kebebasan bertindak dan berusaha). Keempat sifat utama Nabi jika digabungkan dengan nilai keadilan dan nilai khalifah akan melahirkan prinsip freedom to act atau kebebasan bertindak dan 
berusaha bagi setiap muslim. Islam memberikan kebebasan kepada setiap muslim dalam hal Muamalah, namun kebebasan tersebut memiliki batasan-batasan yang tidak boleh dilanggar.

3. Social justice (Keadilan Sosial). Prinsip Social Justice lahir dari gabungan nilai khalifah dan nilai ma'ad. Semua sistem ekonomi yang ada pasti memiliki tujuan yang sama yaitu untuk menciptakan sistem perekonomian yang adil. Keadilan dalam pendistribuasian kekayaan adalah bagian dari prinsip ekonomi Islam. Islam melarang umatnya untuk menumpuk kekayaan pada satu kelompok, namun kekayaan haruslah didistrbusikan secara merata. Kewajiban Zakat, Infak, dan shadaqah bagi golongan yang mampu adalah bentuk pendistribusian kekayaan dalam ekonomi Islam.

Di atas semua nilai dan prinsip tersebut, dibangunlah konsep yang memayungi semuanya yaitu konsep aklak. Akhlak menempati posisi puncak, karena inilah yang menjadi tujuan Islam dan dakwah para Nabi. Akhlaq inilah yang menjadi panduan para pelaku ekonomi dan bisnis dalam melakukan aktivitasnya.

Perbedaan selanjutnya, berkenaan dengan target pencapaian ekonomi. Target ekonomi konvensional, baik ekonomi sosialis maupun kapitalis berorientasikan duniawi semata yang bersifat modern dan berjangka pendek atau bersifat sementara. Sedangkan target pencapaian dalam ekonomi syariah tidak hanya sebatas duniawi dan berjangka pendek, namun juga berorientasikan jangka panjang dan bersifat akhirat atau ukhrawi (mengharapkan pahala dari Allah). Makna filosofis semacam ini jelas tidak ditemukan dalam sistem ekonomi konvensional yang lazim digunakan oleh negara-negara adidaya di dunia. Maka dari itu, tidaklah heran apabila sistem ekonomi kapitalis maupun sosialis tidak pernah mengajarkan para pelaku ekonomi untuk melakukan aktivitas ekonomi sesuai dengan ketentaun Tuhan. 


\section{Transaksi Ekonomi Klasik Masyarakat Aceh}

Sejarah kehidupan masyarakat Aceh memiliki beberapa catatan unik dalam bidang aktifitas ekonomi. Jauh sebelum transaksi-transaksi ekonomi seperti sekarang berkembang, masyarakat Aceh (terutama untuk wilayah Pantai Utara) sudah mempraktikkan aktifitas yang dikenal sebagai bentuk transaksi yang mirip dengan mudharabah, musyarakah, murabahah, dan sebagainya. Praktik-praktik tersebut biasanya dilakukan dalam bidang perniagaan, pertanian (sawah dan ladang) dan peternakan (lembu dan hewan ternak lainnya). Adapaun praktik khas Aceh tersebut adalah mawah, gala, bloe akad, Meudua Laba, Meuniaga, Ngui dll. Dan jika dikaji menurut hukum ekonomi Islam terlihat tidak melanggar.

Dalam sistem Ekonomi Islam, fondasi dasar yang dipergunakan adalah hukum Islam, sedangkan prinsip dasar yang dipergunakan adalah: (1) Pelarangan riba, (2) Pelarangan Gharar/ ketidakpastian, (3) Pelarangan tadlis/penipuan, (4) Pelarangan maisir/spekulasi/judi, (5) Pembatasan aktivitas atau komoditas yang bisa diperdagangkan, seperti tidak boleh terlibat dalam transaksi jual beli daging babi, alkohol, senjata dan amunisi, dll, (6) Penggunaan prinsip bagi hasil (profit and loss sharing). Komponen-komponen tersebut di atas secara garis besar akan menjadi tolak ukur untuk melihat apakah praktik ekonomi masyarakat Aceh seperti mawah, gala, bloe akad, Meudua Laba, Meuniaga, Ngui dll dapat dikategorikan dalam praktik ekonomi syariah yang urgen untuk dilegeslasikan (taqnin). Namun pada tulisan ini, hanya menganalisa tentang gala dan mawah.

Mawah adalah suatu praktik ekonomi yang sangat populer dalam masyarakat Aceh berdasarkan kepada asas bagi hasil antara pemilik modal dengan pengelola. Mawah merupakan suatu mekanisme di mana seorang pemilik aset menyerahkan hak pengelolaan aset tersebut kepada orang lain dengan hasil yang disepakati. Sistem mawah banyak dipraktikkan pada bidang 
pertanian (sawah, ladang, dsb) dan peternakan (lembu, kambing, unggas, dsb) dimana hasil yang dibagikan sangat tergantung pada kesepakatan antara kedua belah pihak. Bagi hasil yang disepakati tergantung pada biaya pengelolaan, baik yang langsung maupun tidak langsung.

Dalam sektor pertanian, misalnya, jika pengelola menanggung segala biaya atas tanaman yang ditanami seperti pupuk, upah pekerja, air, dan lainlain, maka bagi hasilnya mungkin $2 / 3$ untuk pengelola dan 1/3 pemilik modal. Jika lahan tersebut berada jauh dari perkampungan penduduk, bagi hasil yang biasa berlaku dalam masyarakat adalah satu bagian untuk pemilik tanah, tiga bagian untuk penggarap. Untuk praktik mawah dalam bidang peternakan, bagi hasil yang dipraktikkan adalah hasil bersih (net operating income), yaitu harga jual ternak setelah dipelihara selama jangka waktu tertentu dikurangi harga dasar (yaitu harga estimasi ternak pada saat diserahkan untuk dipelihara). Jika yang dimawahkan adalah ternak betina maka bagi hasil adalah nilai jual ternak netto dari penjualan anak ternak. Sedangkan jika yang dimawahkan adalah hewan muda dan belum mempunyai anak (leumo dara) maka bagi hasil yang dilakukan adalah satu bagian untuk pemilik ternak, tiga bagian untuk pemelihara. Intinya adalah bagi hasil selalu disesuaikan dengan hasil netto setelah memperhitungkan manfaat dan biaya plus upaya, (Syamsuddin Mahmud, 2008).

Pada pukat tradisional yang biasa menggunakan perahu kayuh kecil, jaring pukat ditarik melebar sekitar 200 meter dari pantai. Pukat yang telah ditebarkan secara melingkar tersebut kemudian ditarik dengan tangan secara bersama-sama ke darat. Hasil tangkapan berupa ikan tidak semuanya dijual, melainkan sebagian dibagi di antara mereka yang terlibat dalam kegiatan tarek pukat tadi. Jika hasil yang di dapat misalnya 10 keranjang, maka pembagian hasil dapat dirinci sebagai berikut: 2 keranjang akan dibagikan untuk semua penarik pukat yang terdiri (a) pawang pukat mendapat 10\%, (b) pekerja/crew mendapat $40 \%$, (c) pembantu tarek pukat atau awak teumarek yang terdiri 
dari anggota masyarakat setempat mendapat 50\%. Dengan kata lain, 20\% bagian dinikmati oleh pembagian orang lapangan sedangkan $80 \%$ sisanya dijual oleh pawang pukat kepada muge (agen atau pembeli grosir). Selanjutnya, hasil tangkapan tersebut diserahkan oleh pawang pukat kepada pemilik perahu dengan bagi hasil yang disepakati (Fakultas Hukum Unsyiah, 2001).

Berdasarkan penjelasan di atas, secara umum terlihat bahwa praktik mawah mirip dengan praktik mudharabah yang biasa dipraktikkan dalam sistem ekonomi Islam. Dalam praktik mudharabah, seseorang yang mempunyai modal, misalnya modal pertanian berupa tanah, akan memberikannya kepada orang lain untuk digarap yang hasilnya akan dibagi bersama. Kalau yang diberikan mawah adalah sawahnya, sedangkan benih untuk isi sawah tersebut dari petani, biasanya ketika panen hasilnya akan dibagi tiga bagian dengan rincian satu bagian untuk pemilik sawah dan dua bagian untuk petani penggarap. Sedangkan jika pemilik sawah menanggung benih padi ditanami, maka bagi hasil yang ditetapkan adalah 50\% untuk pemilik dan $50 \%$ untuk petani. Bentuk kerja sama mudharabah dengan bentuk seperti mawah ini telah lama dikenal dan banyak dipraktikkan di kalangan masyarakat dunia dengan nama yang berbeda-beda. Bangsa Arab bahkan telah mempraktikkan sistem ini sebelum Islam datang dan terus dipraktikkan oleh Nabi Muhammad SAW baik sebelum maupun sesudah beliau menjadi rasul, contohnya ketika beliau menjadi pedagang kepunyaan Khadijah (Zaki Fuad Chalil, 2008:190). Dalam kasus ini, Khadijah bertindak sebagai pemilik modal (shahibul mal), sedangkan Nabi Muhammad Saw. berperan sebagai pelaksana usaha (mudharib) (Adiwarman A. Karim, 2004:192). Islam sangat menganjurkan bentuk kerja sama seperti ini karena saling menguntung dan membantu mereka yang kurang mampu seperti yang ditegaskan dalam QS. alMuzammil:20, al-Jumu'ah:10, al-Baqarah:198 dan lain-lain. Rasionalitas pembagian hasil ini tentu tidak hanya berbicara untung, tetapi juga ketika rugi. 
Karena itu, istilah ekonomi Islam itu: kama tughram tughnam, sebesar apa risiko yang ditanggung seseorang, sebesar itu pula laba yang berhak diperolehnya (Fauzi Saleh, 2011).

Dalam praktik mawah masyarakat Aceh (biasanya untuk tanah sawah), petani penggarap dituntut untuk secara jujur melaporkan hasil yang diperoleh dari tanah garapannya karena biasanya pemilik tanah tidak memantau langsung hasil panen yang diperoleh oleh petani penggarap; dalam perbankan Islam hal ini disebut sebagai trust financing atau trust investment. Dan jika dilihat secara lebih dalam, praktik mawah dalam bidang pertanian tidak hanya mengandung unsur mudharabah saja, tetapi juga terdapat unsurunsur muzara'ah, mukhabarah dan juga musaqah. Muzara'ah terjadi ketika pemilik sawah tidak menanggung apapun selain memberikan tanah sawah untuk digarap oleh petani. Penggunaan akad mukhabarah terjadi jika bibit untuk sawah tersebut berasal dari pemilik sawah, maka hasilnya akan dibagi dua dengan petani penggarap (Muliadi Kurdi, 2009). Musaqah terdapat dalam beberapa kasus ketika sawah berada di tempat yang jauh sehingga si pemilik meminta orang lain untuk memeliharanya sampai panen.

Dalam tataran ekonomi Islam, praktik mawah sudah memenuhi unsurunsur yang dibolehkan dalam konsep-konsep mudharabah dalam transaksi ekonomi Islam. Unsur-unsur riba, gharar, tadlis, tidak terdapat dalam sistem mawah yang dipraktikkan dalam kehidupan sehari-hari masyarakat Aceh. Pembagian hasil biasanya sudah dijelaskan/diputuskan jauh hari sebelum mawah tersebut dilaksanakan sehingga potensi untuk terjadinya riba sangat minim. Demikian pula unsur ketidakpastian (gharar) dapat diminimalisir dengan adanya kesepakatan awal diantara para pihak yang terlibat dalam praktik mawah tersebut. Karena tujuan awal masyarakat Aceh menerpakan sistem mawah adalah untuk saling bantu membantu, unsur tadlis juga hampir tidak ada. Sistem mawah menuntut kejujuran dari pihak pengelola (atau petani penggarap untuk kasus sawah) dan ini biasanya jalan karena petani 
penggarap berada pada posisi yang memerlukan tanah sawah, sehingga si penggarap tidak berani untuk melakukan manipulasi karena dia masih mengharapkan tanah tersebut kembali diberikan kepada dia pada tahun berikutnya. Walaupun tidak turun langsung ke sawah garapan, pemilik sawah biasanya juga akan melakukan cross check terhadap hasil panen yang diterima dengan membandingkan dengan petani penggarap sekitar.

Adat mawah dapat dikatakan sebagai reaktualisasi transformasi nilainilai Islam dan alternatif dari perekonomian konvensional yang merupakan pranata bunga. Konsep ini memiliki prinsip-prinsip ekonomi Islami, yakni: keikhlasan dan ukhuwwah, kerja dan produktivitas, keadilan distributif, santun lingkungan. Sistem mawah ini kelihatannya sangat perspektif di mana produktivitas kerjanya untuk mencapai tiga sasaran; mencukupi kebutuhan hidup (isyba'), meraih laba yang wajar (irbah) dan menciptakan kemakmuran lingkungan baik sosial terutama pemberdayaan yang tidak mampu maupun alamiah (al-i'mar). Yang membuat sistem mawah dapat diterima secara ekonomi Islam adalah kejelasan atau kesepakatan awal yang dibuat oleh kedua belah pihak, sehingga apapun yang terjadi kemudian tidak lagi berpengaruh terhadap keberlangsungan mawah sehingga para pihak yang terlibat dapat berpikir secara matang tentang keinginan atau keberlanjutan kesepakatan mereka. Jadi secara umum, konsep mawah ini merupakan sistem yang sangat sesuai dengan konteks ekonomi islam. Sekretariat MPU Aceh, Saifuddin di Aula MPU Aceh, Banda Aceh, Rabu (27/7). Mengungkapkan bahwa "Ulama, dai, dan pihak terkait lainnya diminta untuk menyampaikan kepada masyarakat bentuk-bentuk mawah yang sesuai dengan syariat Islam" (http://aceh.tribunnews.com:2017). Pembahasan terkait mawah ini, menurut Saifuddin dilakukan atas pertimbangan bahwa dalam masyarakat Aceh sudah berkembang secara turun temurun tradisi mawah sebagai salah satu bentuk muamalat, dan praktik seperti ini dirasa perlu dilakukan kajian secara mendalam untuk dilegislasikan. 
Sedangkan gala merupakan praktik ekonomi dengan bentuk gadai yang dipraktikkan oleh masyarakat Aceh sejak berabad-abad yang lalu. Gala adalah suatu mekanisme pinjaman di mana seseorang menggadaikan tanah, emas, atau harta benda berharga lainnya untuk memenuhi kebutuhan finansialnya yang mendesak yang biasanya bertujuan untuk memenuhi kebutuhan konsumtif harian. Pada dekade di bawah tahun 80-an, bentuk perjanjian yang dibuat tidak berdasarkan "hitam di atas putih", setelah itu telah mulai menggunakan penjanjian tertulis dengan jangka waktu yang tidak terbatas. Praktik gala ini banyak terjadi dalam bidang pertanian terutama tanah sawah. Hukum adat ekonomi yang dipraktikkan oleh masyarakat Aceh dengan bentuk gadai ini berbeda dengan hukum agraria nasional yang menyebutkan bahwa gadai untuk tanah hanya boleh berlangsung maksima 17 tahun. Setelah waktu 7 (tujuh) tahun berlalu, tanah yang digadaikan harus dikembalikan kepada pemiliknya.

Dalam sistem gala, penggala (pemilik harta) memberikan hak kepada pemegang gala (orang yang memberi pinjaman) untuk menggunakan harta galaan yang dijadikan agunan selama pemilik belum menebus harta tersebut. Hasil yang diperoleh pemegang gala dari penggunaan barang galaan tersebut dianggap sebagai balas jasa atas uang yang dipinjamkan. Pengalihan hak milik atas harta gala hanya dapat terjadi jika pemilik harta yang digalakan mengizinkan hal demikian terjadi. Jika peminjam tidak mampu mengembalikan pinjaman, harta galaan tersebut dapat dijual kepada pihak ketiga dan hasilnya dapat digunakan untuk melunasi pinjaman. Dalam masyarakat Aceh dapat juga terjadi pemegang gala menguasai (membeli) harta galaan tersebut dan membayar sejumlah uang kepada pemilik harta setelah dipotong jumlah pinjaman (Syamsuddin Mahmud, 2008).

Praktik gala dalam masyarakat Aceh sekarang sudah semakin berkurang seiring dengan perkembangan sistem perbankan modern termasuk perbankan Islam. Masyarakat lebih senang berhubungan langsung dengan 
lembaga-lembaga keuangan seperti bank, yang jaringannya sudah sampai ke hampir seluruh pelosok masyarakat, jika memerlukan uang tunai untuk kebutuhan sehari-hari maupun untuk investasi dan modal kerja. Di samping itu, lembaga pegadaian resmi (baik yang mengusung konsep syariah atau konvensional) juga sudah banyak dibuka yang mencakup hampir ke seluruh pelosok Aceh. Modernisasi ekonomi dalam bidang keuangan telah mempengaruhi tatanan tradisional pinjam-meminjam dalam masyarakat Aceh dan perlahan-lahan memudarkan sistem gala.

Praktik gala jika dilihat dalam konteks ekonomi Islam menggunakan sistem gadai (rahn), dimana barang gadaian (marhun) akan dipegang oleh penerima gadai (murtahin) sebagai jaminan selama penggadai (al-rahin) belum menebusnya. Hasil yang diperoleh dari barang gadaian tersebut dianggap sebagai balas jasa atas utang yang dipinjamkan. Secara umum terlihat tidak ada bunga dalam praktik ini. Akan tetapi, dalam praktik sehari-hari, masyarakat yang terikat dengan gala (terutama untuk tanah sawah) sangat susah untuk menebus kembali tanahnya karena ia secara terus menerus dihadapkan pada keadaan terutang tanpa bisa mencari nafkah karena harta benda yang seharusnya digunakan untuk mencari rezeki untuk menebus harta gala tersebut tidak bisa dipakai lagi.

Sementara penerima gala terus menerus menikmati harga gala tersebut tanpa sedikit-pun mengurangi jumlah utang. Hal ini menyebabkan tertindasnya satu pihak oleh pihak lain akibat dari keterikatan dengan perjanjian gala dan mengurangi unsur kerelaan (an taradhim minkum) digantikan dengan keterpaksaan. Secara empiris, orang yang melakukan praktik gala ini adalah orang yang terdesak dari sisi keuangan (orang miskin) sehingga ia menggadaikan tanah atau benda lainnya untuk memperoleh uang dengan cepat dari orang yang punya harta lebih (orang kaya). Karena itulah, mazhab Syafi'i tidak sepakat dengan model gadai seperti itu. Mazhab Syafi'i tidak membolehkan bagi orang yang menerima gadai (al-murtahin) untuk 
memanfaatkan barang gadaian (al-marhun). Jumhur ulama kecuali Hanbali juga berpendapat tidak boleh murtahin memanfaatkan barang gadaian dalam bentuk apa pun. Pemanfaatan dibolehkan sebesar pengeluaran murtahin (penerima gadai) terhadap barang gadaian. Umpamanya penerima gadai boleh menikmati susu sapi gadaian sebanyak makanan yang diberikan untuk lembu.

Jika dikaji lebih jauh, barang gadaian dalam konteks ekonomi Islam memiliki makna filosofis dan sosiologis yang besar; pertama, barang gadai digunakan sekadar untuk memastikan (jaminan) ke-amanah-an si penggadai. Dengan demikian, si piutang tidak akan ragu memberikan sejumlah uang kepada yang berhajat karena ada barang jaminan. Bila penggadai dianggap sangat amanah dan tidak diragukan bahwa ia akan menunaikan utang sesuai dengan perjanjian, tentu barang jaminan tidak diperlukan. Kedua, utang yang merupakan salah satu rukun gadai merupakan media membantu orang lain dan tidak berharap untuk mendapatkan laba dari pemberian utang itu. Prinsip inilah yang melarang pihak piutang mensyaratkan pembayaran tambahan yang akan menjurus menjadi riba. Demikian juga dengan praktik gala, barang galaan hanya sekadar dijadikan jaminan untuk memastikan bahwa orang yang berutang akan membayarnya. Dalam akad rahn, tidak ada istilah pihak yang berpiutang akan rugi dengan memberikan utang kepada pihak lain karena hakikatnya awalnya adalah akad yang bersifat derma. Jadi apa diberikan penggadai kepada penerima gadai tidak untuk ditukar dengan sesuatu. Yang diberikan penerima gadai kepada penggadai adalah utang, bukan penukar atas barang yang digadaikan (Rachmat Syafei, 2001: 159-224). Sementara itu, barang jaminan hanya digunakan sekadar untuk memastikan bahwa orang yang berutang akan melunasi kembali utangnya. Dengan demikian, tidak halal bagi penerima gadai untuk mengambil manfaat dari barang gadaian karena hal tersebut akan menjadi hal terebut sebagai piutang yang mendatangkan 
manfaat. Setiap piutang yang mendatang manfaat adalah riba (M. Sayyid Sabiq, 2011:125-128).

\section{SIMPULAN}

Berdasarkan uraian di atas, dapat disimpulkan bahwa dalam ekonomi Islam, individu tidak menjadi pemeliharaan kekayaan nasional negara dan juga mustahil rakyat semuanya dapat dipaksa pada tingkat ekonomi yang sama. Akan tetapi setiap individu dapat memperoleh kekayaan yang cukup atau tidak berlebih-lebihan untuk memenuhi kebutuhan hidupnya dengan jalan yang baik dan benar agar perputaran harta tidak pada orang-orang kaya saja sehingga tercipta harmonisasi kehidupan dan mampu memapankan sustainable growth atau pertumbuhan yang berkelanjutan. Dan usaha serius di kalangan intelektual atau praktisi hukum Indonesia dan Aceh khususnya, hendaknya terus dilanjutkan agar terbentuknya qanun ekonomi syariah melalui proses legislasi, dan kegiatan ini berjalan seiring dengan proses legislasi hukum ekonomi syariah karena pemerintah telah mengesahkan pemberlakuan hukum Islam di Aceh. Dan hal itu hanya dapat ditempuh dengan pembuatan hukum formal khusus ekonomi syariah di Aceh melalui proses taqnin hukum ekonomi syariah terutama dalam bentuk aktifitas ekonomi khas aceh seperti mawah, gala dan lainnya.

\section{Daftar Pustaka}

Adiwarman Karim. 2004. Bank Islam. Analisis Figh dan Keuangan. Jakarta: PT. RajaGrafindo Persada.

Ali Yafie. Dkk. 2003. Fiqih Perdagangan Bebas. Jakarta: Teraju dan PT. AhadNet Internasional.

'Asham Muhammad Syabaru. 1408 H. Qadhi al-Qudhat fi al-Islam. Beirut: Dar alKutub al-'Arabiyah. 
Atha` Ibnu Khalil. 2000. Taisir Al-Wushul Ila Al-Ushul. Beirut: Darul Ummah.

Bambang Iswanto. 2013. Journal: Ekonomi Islam dan Politik Hukum di Indonesia. Mazahib. Vol. XII No.2. Samarinda: STAIN.

Boediono. 1982. Ekonom Mikro. cet. ke-1. Yogyakarta: BPFE.

Deliarnov. 2006. Ekonomi Politik. Jakarta: Erlangga.

Dinas Syari'at Islam Provinsi Nanggroe Aceh Darussalam. 2010. Himpunan

Undang-Undang. Keputusan Presiden. Peraturan Daerah/Qanun. Instruksi

Gubernur. dan Edaran Gubernur Berkaitan Pelaksanaan Syariat Islam. Ed. 8.

Fakultas Hukum Unsyiah. 2001. Inventarisasi Hukum Adat dan Adat Provinsi Aceh Darussalam. Kerjasama dengan Pemerintah Provinsi Nanggroe Aceh Darussalam. Banda Aceh.

Fauzi Saleh. Edisi 20 May 2011. Mawah. Opini di Harian Serambi Indonesia.

Fazalur Rahman. 1982. Encyclopaedia of Seerah. London : The Muslim Schools Trust.

Gregory Grossman. 1995. Sistem-Sitem Ekonomi. Jakarta: Bumi Aksara.

Heru Sudarsono. 2002. Konsep Ekonomi Islam: Suatu Pengantar. Yogyakarta: Ekonisia.

Husein Umar. 2003. Business an Introduction. cet. ke-2. Jakarta: PT Gramedia Pustaka Utama dan Jakarta Business Research Center.

Jeffry Admund Curry. 2000. terjemahan Erlinda M. Nusron. Memahami Ekoonomi Internasional Memahami Dinamika Pasar Global. Seri Bisnis Internasional. Cet.I. No. 10. Jakarta: PPM.

Jafril Khalil. 2010. Jihad Ekonomi Islam. Jakarta: Gramata Publishing.

Moehammad Hoesin. 1970. Adat Aceh. Aceh: Dinas Pendidikan dan Kebudajaan Propinsi Daerah Istimewa Atjeh.

Muhammad. 2004. Ekonomi Mikro dalam Perspektif Islam. cet. ke-1. Yogyakarta: BPFE.

Muhammad Faruq. al-Nabhan. 1981. Al-Madkh Li al-Tasyri. Cet.Il. Beirut: Dar alQalam.

Muhammad Syahrial. 2012. Journal: Kewenangan DRP Aceh Melegislasi QanunQanun tentang Pelaksanaan Syariat Islam di Aceh Perspektif Hukum Islam. Kualasimpang: Universitas Islam Tamiang. 
Muliadi Kurdi. 2009. Aceh di Mata Sejarawan. Banda Aceh: LKAS.

M. Dawam Rahardjo. 1999. Islam dan Transformasi Sosial-Ekonomi. cet. ke-1. Jakarta: Lembaga Studi Agama dan Filsafat.

M. Sayyid Sabiq. 2011. Fiqh Sunnah. Buku 5. Terj. Mujahidin Muhayan. Cet. III. Jakarta: Pena Pundi Aksara.

M. Umer Chapra. 1999. Islam and the Economics Challenge. Jakarta: The International Institute of Islamic Thought (IIIT). 2000. Masa Depan Ilmu Ekonomi. Sebuah Tinjauan Islam. terj. Ikhwan Abidin Basri. Cet. 1. Jakarta: Gema Insani Press.

Pandji Anoraga. 2004. Manajemen Bisnis. cet. ke-3. Jakarta: Rineka Cipta.

Rachmat Syafei. 2001. Fiqh Muamalah Untuk IAIN. STAIN. PTAIS dan Umum. Bandung: Pustaka Setia.

Robert L. Heilbroner. 1986. Tokoh-Tokoh Besar Pemikiran Ekonomi. Jakarta: UI Press.

Siti Nurhayati. 2009. Ekonomi Syariah: Konsep Pengembangan Model Ekonomi Islam. Semarang: Pustaka Rizki Putra.

Suyud Margono. 2000. ADR dan Arbitrase Proses Pelembagaan dan Aspek Hukum. Jakarta: Ghalia Indonesia.

Syamsuddin Mahmud. 2008. Produktivitas Kerja dan Distribusi Kekayaan dalam Sistem Ekonomi Masyarakat Aceh: Pendekatan Sosio-Kultural. (Pengantar Buku "Horizon Ekonomi Syariah: Pemenuhan Kebutuhan dan Distribusi” oleh Zaki Fuad Chalil) Ar- Raniry Press. Banda Aceh.

Syed Nawab Haider Naqvi. 1994. Islam. Economics and Society. London and New York: Kegan Paul International.

S. Waqar Ahmed Husaini. 2002. Islamic Sciences. New Delhi: Goodwork Book.

Taqiy Al-Din An-Nabhani. 1990. An-Nizham Al-lqtishadi fi Al-Islam. Beirut: Dar Al-Ummah.

Zaki Fuad Chalil. 2008. Horizon Ekonomi Syariah: Pemenuhan Kebutuhan dan Distribusi Pendapatan. Ar-Raniry Press. Banda Aceh. 


\section{Daftar Website}

Agustianto. Kegagalan Kapitalisme; Perspektif Ekonomi Islam; www.waspadaonline.com. diakses tanggal 9 Mei 2017.

http://aceh.tribunnews.com/2016/07/28/mpu-qanunkan-sistem-mawah-sesuaisyariat. diakses tgl. 28 Maret 2017. 